\title{
Geographical and Operational Focus/Diversification Reexamined. Acquisition Frequency, Deregulation, and Announcement Returns from Bank M\&AS
}

\author{
Allissa Lee \\ Georgia Southern University \\ David Carter \\ Oklahoma State University
}

We examine bank merger and acquisition announcement returns during a time of industry deregulation and find little evidence supporting either a diversifying or focusing argument from a geographical or operational viewpoint. Overall, deals generate negative acquirer returns. Our study suggests that regulatory environment and acquirer acquisition appetite impact returns. Infrequent acquirers experience lower returns during the deregulatory period compared to deals announced outside the deregulatory period, and to more frequent acquirers. Might these results suggest more frequent acquirers had developed superior knowledge and expertise which they were able to exploit in the new environment, implying that repetition helps facilitate success?

\section{INTRODUCTION}

The corporate landscape changes continuously and companies utilize various methods to gain strategic advantage, remain competitive, and stay relevant as well as to achieve specific operational and/or strategic goals to increase firm value and shareholder wealth. Many firms view mergers and acquisitions (M\&As) as an attractive strategic option to reach goals such as increasing market power or market share, eliminating competition, realizing economies of scope, etc. because goals may be realized much more quickly than through more organic paths.

Bruner (2004) states "...the M\&A transaction delivers a premium return to target firm shareholders" (p. 36). Existing research consistently concludes that acquisitions yield positive announcement returns for target firm shareholders (DeLong, 2001; Houston, James, \& Ryngaert, 2001). Evidence surrounding the impact on market valuations and performance for acquirers is much less consistent. Bouwman, Fuller, and Nain (2009), for example, find acquiring firm shareholders lose substantial value following an acquisition. Other research, however, shows positive bidder returns (Moeller, Schlingemann, \& Stulz, 2003) or positive returns for both target and bidder (Cornett \& De, 1991a). Bruner (2004) summarizes M\&A literature to-date and finds 43 percent (26 percent) of studies reviewed indicate significant positive (negative) returns, with 31 percent reporting insignificant returns. Moeller, Schlingemann, and Stulz (2005) estimate mergers and acquisitions erased \$240 billion in shareholder wealth in 1998-2001.

Impacts spread beyond stock price. Accounting-focused studies indicate mergers and acquisitions are unfavorable for acquirers (Dickerson, Gibson, \& Tsakalotos, 1997; Knapp, Gart, \& Becher, 2005). 
Sherman and Rupert (2006) contend disappointing M\&A returns may be attributable to implementation delays of cost-saving strategies and other sources of synergy and benefit. M\&A costs can be substantial. As such, Houston and Ryngaert (1994) caution against interpreting accounting results too closely to the merger itself because one-time merger-related costs can overshadow cost-cutting gains for years.

Despite the absence of consistent favorable performance, bidding firms still largely rely on expectations of synergies, which provide the increase in firm value, to support M\&A proposals and bolster market confidence in deal outcomes (Houston \& Ryngaert, 1994). In this research, we explore a subset of merger transactions, focusing on two primary measures of firm synergy/diversificationgeographical (locational) and operational (activity). The focusing hypothesis predicts that firms acquiring targets that are similar in location or activity will be better off, largely due to expected synergies from various cost-cutting efforts, increases in economics of scope, etc. Of course, the opposite diversification hypothesis suggests mergers that diversify the bidding firm geographically or operationally are beneficial due to risk spreading and access to new revenue.

The increased merger activity of the 1990s and 2000s, which began in the United States (US) and spread worldwide (Huyghebaert \& Luypaert, 2013), did not bypass the financial industry. FDIC ${ }^{1}$ data show the number of commercial banks and savings institutions dropped by more than 6,500 during our sample period (nearly 45 percent). Regulatory ${ }^{2}$ changes set off a wave of industry consolidation as the M\&A environment became much more attractive for financial sector deals.

The passage of the Riegle-Neal Interstate Banking and Branching Efficiency Act of 1994 (RN Act) and the Gramm-Leach-Bliley Financial Services Modernization Act of 1999 (GLB Act) ushered in a new era in US banking. The RN Act allowed for interstate banking and the GLB Act lifted the separation requirement of certain financial services firms, in particular banks and securities firms, but also insurance and financial advisory service firms. Taken together, the RN and GLB Acts resulted in substantial industry deregulation, providing opportunity for industry consolidation as well as operational and geographical growth, largely prohibited for decades.

Brewer, Jackson, Jagtiani, and Nguyen (2000) and Hughes, Lang, Mester, and Moon (1999) note the regulatory changes encouraged geographic expansion across state lines, in particular, but intrastate consolidations increased as well. Motives for intrastate expansion could include growth to (1) compete with larger in- and out-of-state banks; (2) become a more attractive takeover target; or (3) fend off wouldbe acquirers (Gorton, Kahl, \& Rosen, 2009). Industry deregulation most benefited acquirers who reorganized into a more efficient form and lowered costs by reducing paperwork and eliminating overlapping functions (Becher, 2009) and/or improved their general operating efficiency (Cornett, McNutt, \& Tehranian, 2006).

Deregulation altered the banking merger and acquisition environment substantially (Flannery, 1999; Becher \& Campbell, 2005). The renewed ability of financial institutions to diversify into new geographic and/or operational areas increased M\&A activity and likely propelled many firms into the M\&A market. Brewer et al. (2000) note that deregulation significantly lowered barriers to entry, increased competition for targets, and increased merger prices. Substantial changes in merger performance resulted (Becher \& Campbell, 2005). Houston et al. (2001) suggest merger methods and practices improved over time. Hence, existing research may not be indicative of future M\&A performance. At best, empirical results are mixed with respect to focusing versus diversifying mergers (DeYoung, Evanoff, \& Molyneux, 2009).

Acquisitions that focus the bidder geographically (intrastate mergers) should tend to be easier and, therefore, less costly before, during, and after merger completion. State banking regulations differ from state to state. Accordingly, merger related costs for performing due diligence, obtaining regulatory approval, and achieving complete integration will be lower for a geographically focusing versus diversifying target. Becher (2009) and Schmid and Walter (2012) suggest better post-merger performance occurs due to lower costs associated with monitoring, compliance, and reporting for the newly acquired firm which is geographically focusing versus diversifying. Consequently, a geographic "synergy" exists that leads to a more positive market reaction, resulting in higher returns. Recent research notes a negative association between geographic diversification and firm performance/market valuation (Goetz, Laeven, \& Levine, 2013; Jouida, Bouzgarrou, \& Hellara, 2017), which Schmid and Walter (2012) do not find. Yet, 
Cornett and De (1991a) argue that positive announcement returns may be attributable to merger associated geographic expansion opportunities. Still, other research indicates neither geographically focusing nor diversifying mergers add value to the bidder (DeLong, 2001). Berger and DeYoung (2001) conclude that the positive or negative effects of geographic diversification are largely firm dependent and does not necessarily have to impact performance. Becher and Campbell (2005) note positive returns for large, geographically focusing mergers prior to industry deregulation but the opposite afterward.

Likewise, if the target and acquirer are similar in the activities performed, then combining the two firms is less difficult. Additionally, the new, combined firm eliminates overlapping activities, reduces costs, and emerges much more seamlessly as a consolidated firm; nor are scarce resources (time, money, staff, etc.) allocated to learning a new business as well as industry practices and regulations. For instance, combining two depository institutions requires much less assimilation effort than merging a depository institution and an insurance or securities firm. Consequently, the market views the former more positively since it creates an industry "synergy." Given the high degree of relative homogeneity, resulting in higher shareholder returns, operational/activity synergy benefits should be greater in the banking industry. Consolidating mergers eliminate competitors and increase market share, which could increase acquirer returns.

Undertaking a merger or acquisition is one method to quickly achieve revenue stream diversity for a bank. Diversifying firm revenues to rely less on traditional sources, like interest income on loans, to noninterest fee income can reduce risk associated with nonperforming assets, however. Stiroh (2004) notes many banks are focusing on increasing noninterest income generation but finds limited benefits to such diversification. Noninterest income is more volatile than interest income and contributes to higher revenue and profit volatility. Knapp et al. (2005) link poor post-merger performance in banking industry deals to noninterest income declines. Sawada (2013) finds that revenue diversification positively impacts firm market value.

Markets value acquisitions with high operational overlap (Houston \& Ryngaert, 1994; Sudarsanam, Holl, \& Salami, 1996). Synergistic gains generated in intra-industry mergers are largely attributable to operational synergies available, whereas inter-industry mergers are dependent upon other sources (Sudarsanam et al., 1996). Merging banks with strategic similarities result in better performance while those without may be viewed less positively or as less desirable (Ramaswamy, 1997). Some studies find no substantial cost savings from mergers (Houston \& Ryngaert, 1994); however, Houston et al. (2001) note that projected merger gains are mostly associated with cost savings from eliminating overlapping operations. Laeven and Levine (2007), Schmid and Walter (2009), and Jouida et al. (2017) find that operationally diversified firms are discounted relative to focused firms. DeLong (2001) concludes that neither operationally focusing nor diversifying mergers add value to the bidding firm.

Some acquisition targets allow the bidder to dually diversify or focus, permitting the acquirer to "double-down" on its strategic objective. Existing research finds that acquisitions that focus both location and activity increase shareholder value (DeLong, 2001; Cornett et al., 2006); however, Jouida et al. (2017) show firm performance is positively associated with dually diversifying deals.

Cornett and Tehranian (1992) and Cornett et al. (2006) connect superior merged bank performance to the aptitude of the combined firm to create new business, improve employee productivity, and grow assets. Merger associated revenue increases and cost reductions further enhance operating performance. Houston and Ryngaert (1994) and Egger and Hahn (2010) find that horizontal mergers positively influence performance.

Given the degree of industry consolidation, many firms participated in the merger and acquisition market, some more frequently and successfully than others. Ismail (2008) notes frequent (serial) acquirers perform worse than infrequent (nonserial) acquirers; however, other research reports no difference in performance (Ooghe, De Langhe, \& Camerlynck, 2006). Laamanen and Keil (2008), Boubakri, Chan, and Kooli (2012), and Al Rahahleh and Wei (2012) find lower returns for higher order deals, but Croci and Petmezas (2009) find no evidence of performance persistence or reversal for frequent acquirers. The underlying motivation to engage in mergers may not be that different for serial and nonserial acquirers: 
growth. The appetite for acquisitions and characteristics of firms targeted likely varies considerably, however. Ooghe et al. (2006) find that multiple acquirers prefer targets that complement their own firms.

Our study documents returns for serial and nonserial bank acquirers from M\&A announcements given the geographical and/or operational focusing/diversifying nature of the deal. Additionally, we consider industry-based regulatory changes. Accordingly, our study adds the following contributions to existing literature.

First, previous studies explore geographic and operational focus and/or diversification effects, but most merger and acquisition studies ignore acquirer acquisition frequency. Harford, Humphery-Jenner, and Powell (2012) include a serial acquirer measure; however, they specifically exclude financial firms. To our knowledge, no study exists that incorporates this acquirer characteristic in the context of announcement returns resulting from focusing/diversifying mergers and acquisitions for financial firms.

Second, we include private and subsidiary targets (not publicly traded), which other studies disregard, in conjunction with focusing/diversifying acquisitions for banks. Harford et al. (2012) include nonpublicly-traded targets but, as previously noted, specifically exclude financial firms. Other referenced studies that explore synergy/diversification either (1) do not examine mergers and acquisitions; or (2) do not focus on, or at least include, financial firms. Previous research finds that returns from acquisitions of nonpublic firms exceed those of public firms (Fuller, Netter, \& Stegemoller, 2002; Hansen \& Lott, 1996), so their inclusion is important.

Third, our sample period includes substantial industry deregulation, which impacts M\&A activity and returns. Becher (2009) and Brewer et al. (2000) explore merger and acquisition returns around this industry event but do not incorporate the degree of bidder acquisition activity or nonpublicly traded targets.

Consistent with existing literature, acquisitions in our sample generate negative acquirer returns. The bidder's acquisition frequency affects target choice and shareholder returns. With few exceptions, the target firm's contribution to the focusing/diversifying objective of the bidder does not impact bidder returns. Additionally, we find deregulation affected returns. Our results suggest somewhat that more frequent acquirers utilize superior knowledge, developed through M\&A deal experience, to take advantage of the new operating environment.

The paper continues as follows: Next, we present our data and methodology. After which, we provide our empirical results and lastly conclude.

\section{DATA AND METHODOLOGY}

\section{Data}

The sample includes mergers and acquisitions announced between January 1, 1990, and December 31, 2007, ${ }^{3}$ as listed in Thomson Financial's SDC Mergers and Acquisitions Database (SDC). To be included in the sample, the announcement and completion dates, form of financing, target public status, and deal value must be available. The following additional conditions must be met:

- The acquirer is a publicly-traded, US-based firm.

- The target is a publicly-traded, private or subsidiary firm, based in the US.

- The transaction results in the acquirer obtaining majority control with more than 50 percent ownership in the target.

- The deal is completed with a deal value greater than $\$ 1$ million US.

- The acquirer's three-digit SIC code is 602/603 (depository institution) or 6712/6719 (bank holding company).

- Sufficient price information exists on the Center for Research and Security Prices (CRSP) database to compute cumulative abnormal returns for the acquirer.

- The Y-9C Bank Holding Company Reports (available from the Federal Reserve Bank of Chicago) contain sufficient accounting information to compute return-on-assets (ROA) and return-on-equity (ROE) for the acquirer. 
We estimate returns over a five-day window around the announcement ( \pm 2 days). We exclude deals with the following characteristics: (1) the acquirer's stock price one month prior to announcement is less than $\$ 2$ (US) per share (avoid bid-ask bias); (2) the deal results from a bank failure (per the FDIC failed bank list); or (3) the bidder has multiple announcements within the event window (impossible to differentiate between the effects of the events).

We include the acquisition frequency of the acquirer as several studies document differences in returns between serial (frequent) acquirers and nonserial (unique/infrequent) acquirers (Fuller et al., 2002; Ismail, 2008). We classify bidders as serial or nonserial acquirers according to the definition of Fuller et al. (2002), which says that a serial acquirer is a firm that makes five or more successful bids within any three-year window during the sample period, otherwise the firm is considered a nonserial acquirer.

The final sample consists of 1,382 acquisition announcements made by 318 firms. Figure 1 reports the number of acquisitions by year, showing a substantial increase in activity between 1992 and 1999. Serial acquirers engage in more deals during this time period than the rest of the sample period.

\section{FIGURE 1 \\ NUMBER OF ACQUISITIONS BY YEAR}

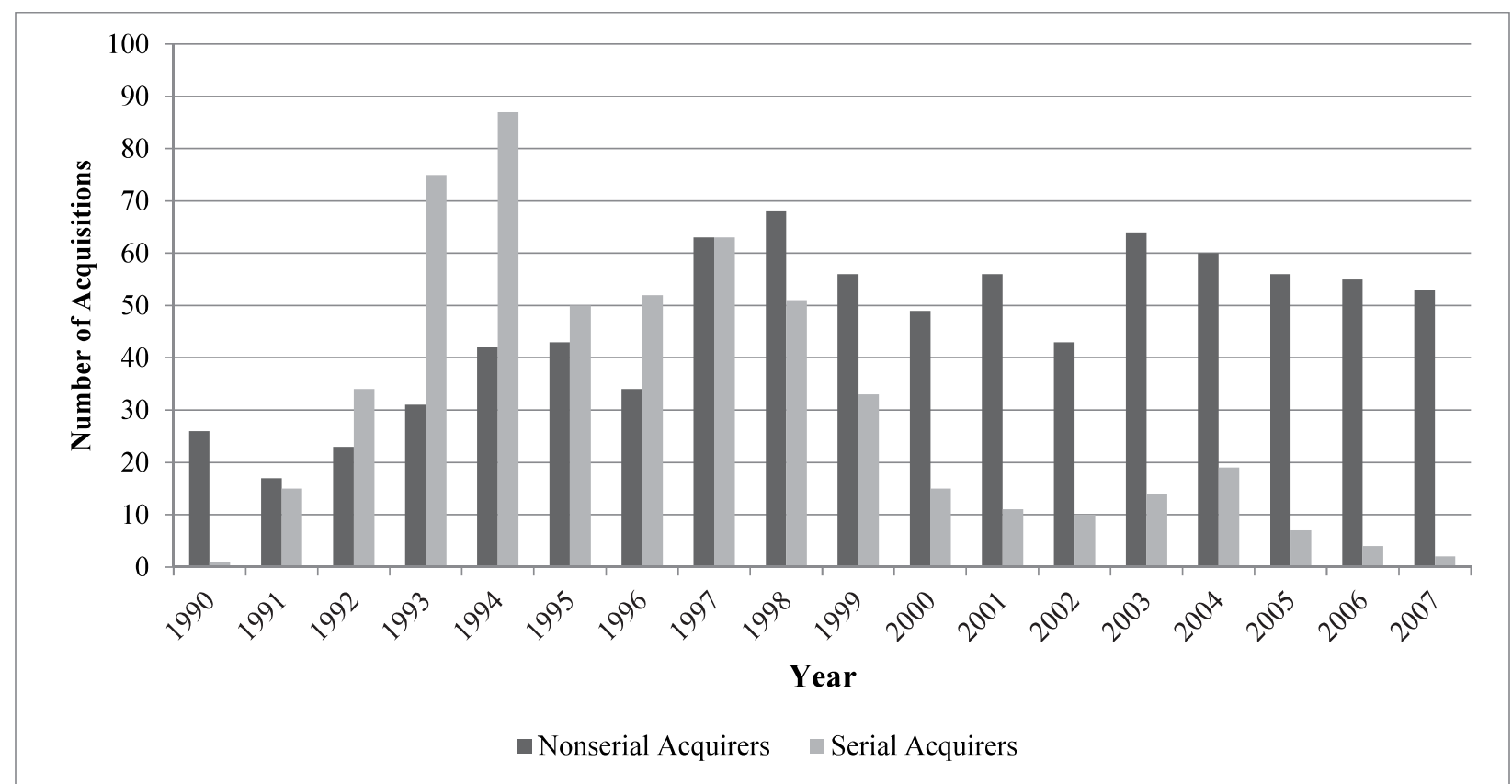

Note: In this figure, we present the number of acquisitions announced each year, based on the acquisition frequency of the bidder. Total acquisitions for the year is the combined total of acquisitions announced by serial and nonserial acquirers.

\section{Methodology}

We use standard event study methodology, as suggested by Brown and Warner (1985), to investigate market reaction to merger announcements. Similar to work by Fuller et al. (2002) and Ismail (2008), our primary metric of analysis is the five-day cumulative abnormal return (CAR) observed over the two days before and after a merger announcement. We use an estimation window of $(-210,-21)$ days before the merger announcement in our CAR calculation. Each bidder must have at least 30 days of security prices available. The CRSP value-weighted index serves as the benchmark for the market.

Our study focuses on determining if differences in returns exist for acquisitions that focus or diversify the bidder geographically and/or operationally, conditional on the bidder's acquisition frequency. Further, we investigate returns during industry deregulation. Of course, bidders engage in deals that provide dual diversification/focus or a mixture of both and we examine those deals as well. Accordingly, we create variables to account for location and activity similarity. 


\section{Geographical/Locational Synergy}

We define geographical/locational synergy based on whether the target and bidder are in the same state, a measure also used by DeLong (2001). By acquiring an out-of-state bank, the acquirer obtains assets that are likely less correlated, in terms of value, than in-state assets, and can improve economies of scale. While diversification can be beneficial, so can focus (synergy). Operating in multiple markets can spread valuable resources thin, increase operational costs as well as compliance and reporting costs, and enhance agency issues due to ineffective monitoring of management (Becher, 2009; Schmid \& Walter, 2012; Goetz et al., 2013).

\section{Operational/Activity Synergy}

To measure operational (activity) synergy, some studies use stock price correlation (DeLong, 2001) and/or SIC code similarity (Walker, 2000; Sudarsanem et al., 1996). We use the two-digit SIC code (collected from SDC). This classification method is favorable because the entire sample is retained.

While this measure has been used in prior literature (DeLong, 2001), it tends to be a fairly blunt measure of operational focus/diversification, particularly given the homogeneous nature of classification by SIC code of the banking/financial services industry (approximately 95 percent of the sample belongs to the same two-digit SIC code). To better measure acquirer-target activity similarity, we construct two measures using financial statement data retrieved from each firm's Y-9C Reports. Unfortunately, we lose some of our sample due to the unavailability of target data.

The first measure, BS_SIM, computes the sum of the squared differences in the proportion, relative to total assets, made up by various types of loans. Interest income from loans is the primary source of bank income. If a bidder is seeking to diversify/focus its activities, the bidder would pursue targets that fit that strategic objective. We use real estate, commercial, agricultural, and personal loan data for each bidder and target firm pair to measure the asset composition of the target relative to the bidder. As such, this variable directly measures the extent of similarity/dissimilarity between the loan-assets of the acquirer and target. We compute BS_SIM for each of our bidder and target pairs as follows:

BS_SIM $=\sum_{i=1}^{n}\left(\frac{L_{i, \text { Acquirer }}}{T A_{\text {Acquirer }}}-\frac{L_{i, \text { Target }}}{T A_{\text {Target }}}\right)^{2}$,

where:

$\mathrm{L}_{\mathrm{i}, \mathrm{Acquirer}} \quad=\quad$ Loan type $\mathrm{i}$ for the acquiring bank,

$\mathrm{L}_{\mathrm{i}, \text { Target }}=$ Loan type $\mathrm{i}$ for the target bank,

$\mathrm{TA}_{\mathrm{Acquirer}}=$ Total assets for the acquiring bank, and

$\mathrm{TA}_{\text {Target }}=$ Total assets for the target bank.

We measure the similarity/dissimilarity of the income sources for the bidder and target using the variable IS_SIM. This variable is similar in concept to BS_SIM, but uses firm income information from the income statement. Historically, interest income has been the primary revenue source for banks. Recently, firms have been seeking sources of noninterest income (Stiroh, 2004). If a firm is in the market to focus (diversify) its revenue sources, then the firm will target firms with more similar (dissimilar) revenue sources to their own. We utilize interest income and noninterest income, scaled relative to total operating revenue (interest income plus noninterest income), to determine the relative similarity/dissimilarity of the income sources for acquirer-target pairs and create our income similarity variable. IS_SIM is calculated as 
$I S_{S I M}=\sum_{i=1}^{n}\left(\frac{I N C_{i, \text { Acquirer }}}{\text { TOR }_{\text {Acquirer }}}-\frac{I N C_{i, \text { Target }}}{T O R_{\text {Target }}}\right)^{2}$

where:

$\mathrm{INC}_{\mathrm{i}, \mathrm{Acquirer}}=\quad$ Income statement item $\mathrm{i}$ for the acquiring bank,

$\mathrm{INC}_{\mathrm{i}, \text { Target }}=$ Income statement item i for the target bank,

$\mathrm{TOR}_{\text {Acquirer }}=\quad$ Total operating revenue for the acquiring bank, and

$\mathrm{TOR}_{\text {Target }}=$ Total operating revenue for the target bank.

\section{Other Factors}

We include a variety of other explanatory and control variables, accounting for deal and firm characteristics, which the M\&A literature shows impacts CARs. Existing research finds that acquirer size (Moeller, Schlingemann, \& Stulz, 2004), relative size (DeLong, 2001; Gupta \& Misra, 2007; Ismail, 2008), bidder profitability (Houston \& Ryngaert, 1994), target public status (Hansen \& Lott, 1996; Chang, 1998; Moeller et al., 2003) and form of financing (Cornett \& De, 1991b; Houston \& Ryngaert, 1994) influence announcement returns. We measure acquirer size by market capitalization one month prior to announcement. We utilize deal value (captured from SDC) as a proxy for target size since many targets are not publicly traded. Relative size is the ratio of target size to acquirer size. Profitability is measured by ROE. We collect net income and total equity from firm Y-9C Reports and target public status and method-of-payment information from SDC.

We additionally include the geographical and/or operational similarity variables to account for deal diversification and/or focus (Intrastate, SIC_SIM, BS_SIM and IS_SIM classifications). We include a dummy variable that denotes deals announced during the deregulatory period.

TABLE 1

ACQUIRER AND TARGET CHARACTERISTICS

\begin{tabular}{|c|c|c|c|}
\hline Acquiring Firms & All & Serial & Nonserial \\
\hline \multicolumn{4}{|l|}{ Target Public Status } \\
\hline Public & 649 & 247 & 402 \\
\hline Nonpublic (Private \& Subsidiaries) & 733 & 296 & 437 \\
\hline \multicolumn{4}{|l|}{ Acquirer Firm Size } \\
\hline Market Capitalization (millions of US dollars) & 5,452 & 5,823 & 5,212 \\
\hline Total Assets (millions of US dollars) & 29,419 & 30,201 & 28,913 \\
\hline \multicolumn{4}{|l|}{ Acquirer Profitability } \\
\hline Net Income (millions of US dollars) & 334 & 359 & 318 \\
\hline ROE & $12.97 \%$ & $13.02 \%$ & $12.93 \%$ \\
\hline ROA & $1.12 \%$ & $1.07 \%$ & $1.16 \%$ \\
\hline Deal Value (millions of US dollars) & 266 & 184 & 318 \\
\hline \multicolumn{4}{|l|}{ Target Firms } \\
\hline \multicolumn{4}{|c|}{ Target Firm Size and Profitability**For firms with reported information. } \\
\hline Total Assets (millions of US dollars) & 1,569 & 1,336 & 1,717 \\
\hline Net Income (millions of US dollars) & 31 & 28 & 33 \\
\hline
\end{tabular}

In Table 1, we provide summary statistics for acquirers and targets. A majority of targets are not publicly traded. Acquirers are sizeable and considerably larger than targets. In general, we cannot document substantive differences between serial and nonserial acquirers for size, net income, or profitability. 
TABLE 2

AVERAGE ACQUIRER AND TARGET ASSET AND

INCOME RATIOS BY ACQUIRER SERIAL STATUS

\begin{tabular}{|c|c|c|c|c|c|c|}
\hline Average & RE_Loans & CML_Loans & AG_Loans & PER_Loans & INT & NONINT \\
\hline \multicolumn{7}{|l|}{ Acquiring Firms } \\
\hline Nonserial Acquirers & $41.07 \%$ & $11.99 \%$ & $0.59 \%$ & $8.07 \%$ & $82.54 \%$ & $17.46 \%$ \\
\hline Serial Acquirers & $34.26 \%$ & $13.15 \%$ & $0.81 \%$ & $10.33 \%$ & $82.75 \%$ & $17.25 \%$ \\
\hline Range & $6.81 \%$ & $1.15 \%$ & $0.22 \%$ & $2.25 \%$ & $0.21 \%$ & $0.21 \%$ \\
\hline \multicolumn{7}{|l|}{ Target Firms } \\
\hline Nonserial Acquirers & $45.13 \%$ & $11.37 \%$ & $0.75 \%$ & $6.05 \%$ & $88.67 \%$ & $11.33 \%$ \\
\hline Serial Acquirers & $38.00 \%$ & $10.86 \%$ & $1.14 \%$ & $8.21 \%$ & $88.56 \%$ & $11.44 \%$ \\
\hline Range & $7.13 \%$ & $0.51 \%$ & $0.38 \%$ & $2.16 \%$ & $0.11 \%$ & $0.11 \%$ \\
\hline
\end{tabular}

We break down the BS_SIM and IS_SIM variables as follows: real estate, commercial, personal, and agricultural loans, each scaled to total assets (RE_Loans, CML_Loans, PER_Loans, and AG_Loans, respectively) as well as noninterest and interest income, relative to total operating revenue (NONINT and INT, respectively) to examine target and bidder characteristics. Nonserial acquirers tend to hold a higher percentage of real estate loans relative to serial acquirers and prefer targets with a similar loan-asset structure, as indicated in Table 2. Serial acquirers, however, hold higher commercial, agricultural, and personal loan percentages than nonserial acquirers. Their targets, however, maintain lower commercial loan percentages, but higher agricultural and personal loan percentages. Largely, we find no substantive difference in the interest income percentage and noninterest income percentage of serial and nonserial acquirers or their targets.

\section{EMPIRICAL RESULTS}

In addition to univariate analysis, we perform cross-sectional analyses to control for deal and acquirer characteristics. We report results using robust standard errors to account for any heteroskedasticity present in the data.

\section{Focus Versus Diversification}

Our sample indicates serial acquirers engage in more geographically-diverse deals than nonserial acquirers, which tend to buy in-state instead of diversifying operations into other states (Table 3). We find most acquisitions focus rather than diversify firm operations, as most targets and bidders belong to the same two-digit SIC code. We find similar results using the alternate activity classifications: more acquisitions involve targets with similar asset and income compositions as the bidder. 
TABLE 3

FIVE-DAY ANNOUNCEMENT PERIOD CUMULATIVE ABNORMAL RETURNS (CARS) BY DIVERSIFICATION/FOCUS TYPE

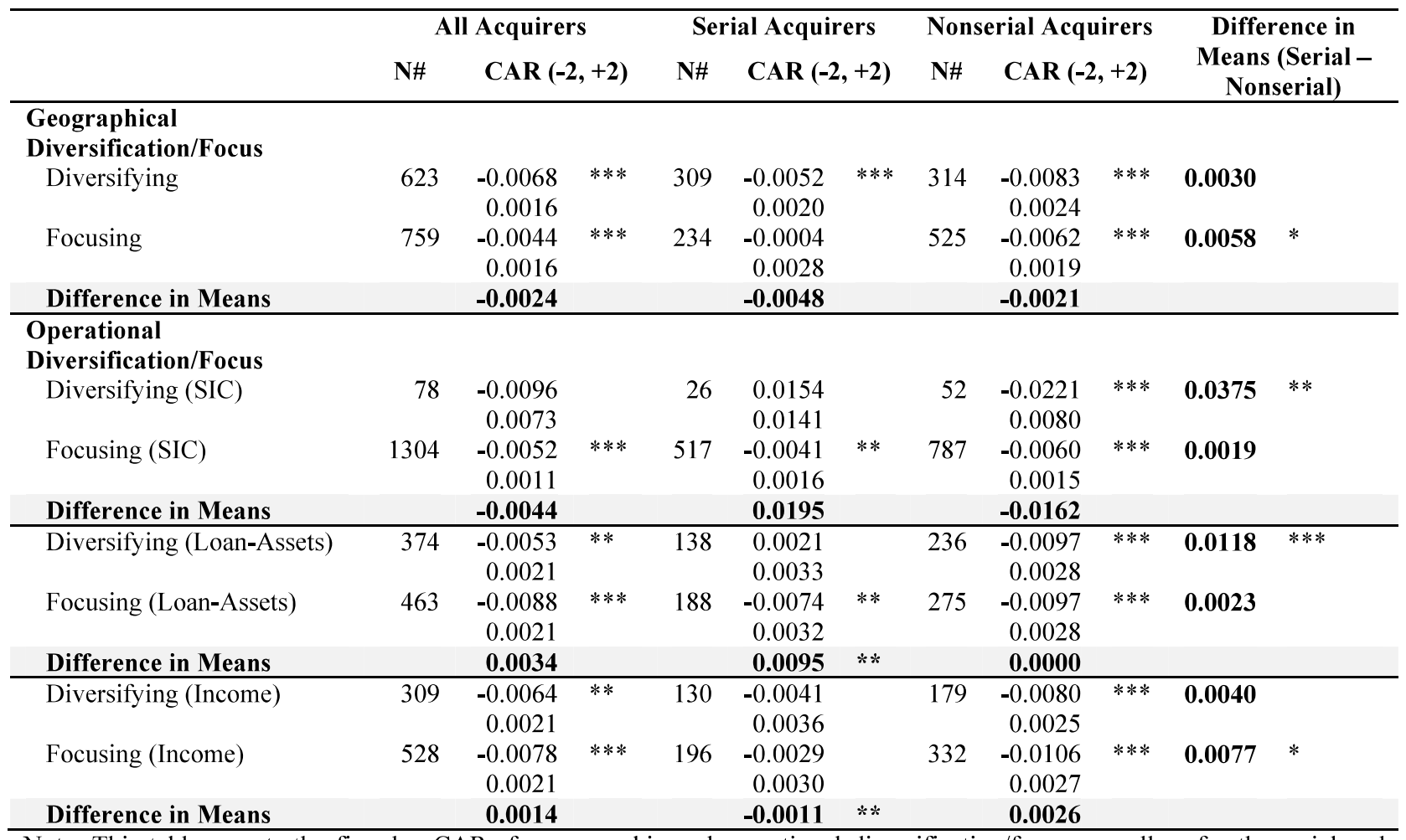

Note: This table reports the five-day CARs for geographic and operational diversification/focus as well as for the serial and nonserial acquirer subsamples. Standard errors are reported below the mean CAR and statistical significance is indicated by $* * *$, $* *$, and $*$ for $1 \%, 5 \%$, and $10 \%$, respectively.

We find that returns are mostly negative and significant. With few exceptions, we document little evidence of differences in market reaction to acquisition announcements based on the diversifying/focusing aspect of the target from a geographic or operational perspective. Largely, we find the same results for the nonserial acquirers subsample. Examination of the serial acquirers subsample reveals some differences. For one, less than half of the returns are negative, and the remainder are statistically insignificant. Second, asset focusing acquisitions generate lower returns than asset diversifying deals; the opposite holds for income diversification/focus. Last, our results indicate that serial acquirers outperform nonserial acquirers when the acquisition (1) focuses the bidding firm geographically; (2) diversifies the bidder's activities based on the 2-digit SIC code; (3) diversifies the bidding firm's activities based on asset composition; or (4) focuses the bidding firm's activities based on income composition.

Our results are consistent with DeLong (2001) and Schmid and Walter (2012) but contrary to conclusions reached by Goetz et al. (2013) for geographic diversification/focus. From an operational diversification/focus viewpoint, our findings are inconsistent with the diversification discount outcomes noted by Laeven and Levine (2007), Schmid and Walter (2009) and Jouida et al. (2017). Our results do; however, suggest performance is contingent upon the acquisition frequency of the bidder. Some existing studies indicate that serial acquirers underperform nonserial acquirers (Ismail, 2008, for example) while others find no difference in performance (Ooghe et al., 2006); however, we find that serial acquirers perform better than nonserial acquirers. 
TABLE 4

FIVE-DAY ANNOUNCEMENT PERIOD CUMULATIVE ABNORMAL RETURNS (CARS) BY DUAL DIVERSIFICATION/FOCUS TYPE

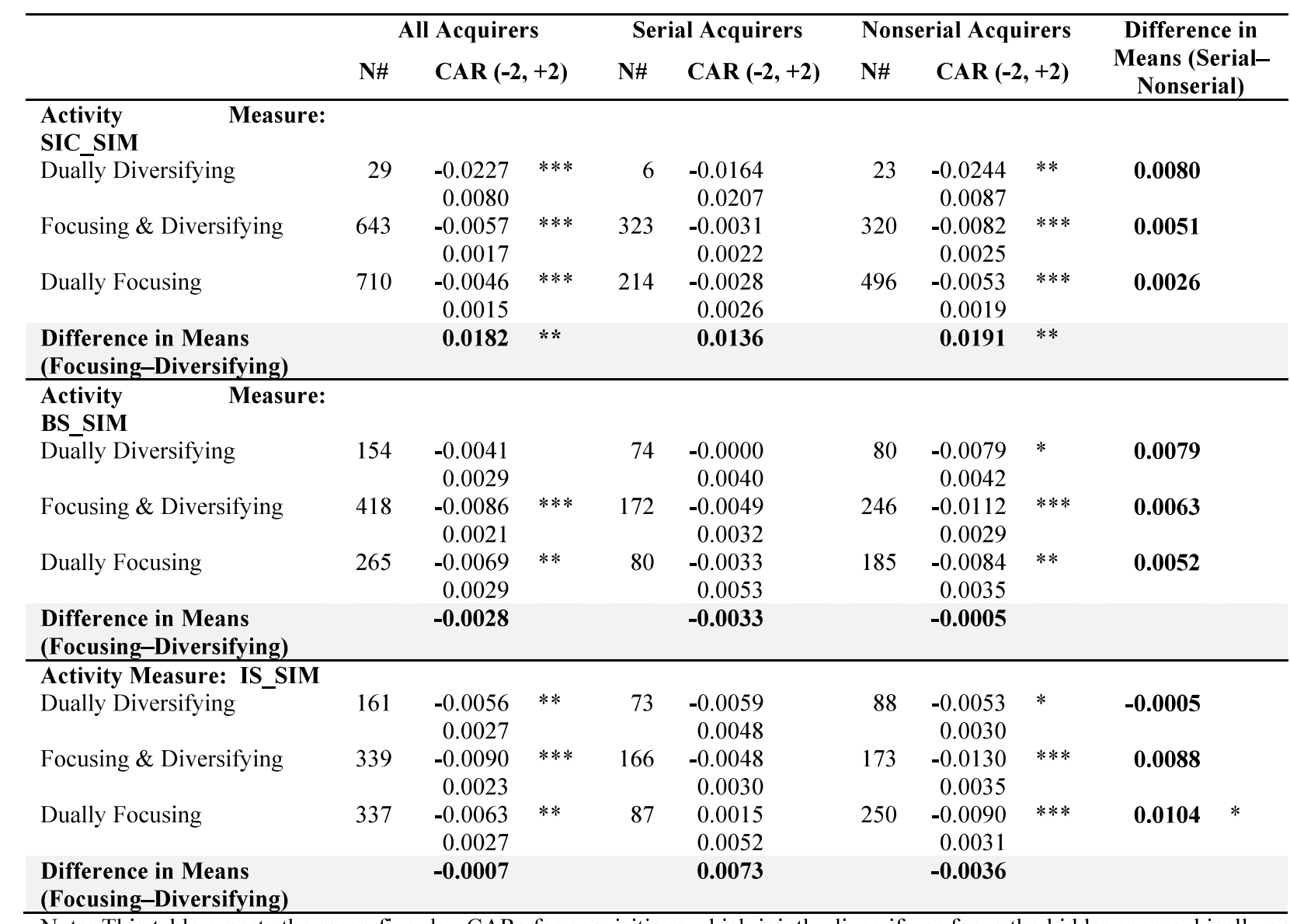

Note: This table reports the mean five-day CARs for acquisitions which jointly diversify or focus the bidder geographically and operationally as well as deals which combine diversification and focus. We classify the sample into serial and nonserial acquirer subsamples. Standard errors are reported below the mean CAR and statistical significance is indicted by $* * *, * *$, and $*$ for $1 \%$, $5 \%$, and $10 \%$, respectively.

Given the dual focus/diversification findings of DeLong (2001) and Jouida et al. (2017), we examine the results of these deals in Table 4. Our results show most acquisitions either jointly focus the bidder or provide a mix of focus/diversification, with few acquisitions jointly diversifying the bidder.

Generally, we find negative returns for the full sample and the nonserial acquirers subsample and insignificant returns for the serial acquirers group. Regardless, we cannot document a significant difference in returns between serial and nonserial acquirers, except in one case (dual focus: IS_SIM, 10\% level). With respect to dually focusing/diversifying deals, we find two occurrences of significant differences in returns: the full sample and the nonserial subsample (SIC_SIM), with dually focusing acquisitions yielding nearly a 2 percent return premium. In unreported results, we uncover significant differences in returns between dually diversifying acquisitions and mixed diversifying/focusing acquisitions consistent with DeLong (2001); but inconsistent with Jouida et al. (2017) and the reverse is true for dually focusing mergers. 
TABLE 5

FIVE-DAY ANNOUNCEMENT PERIOD CUMULATIVE ABNORMAL RETURNS (CARS) BY REGULATORY ENVIRONMENT

\begin{tabular}{|c|c|c|c|c|c|c|c|c|c|c|}
\hline \multirow[b]{3}{*}{ Deregulatory Period } & \multicolumn{3}{|c|}{ All Acquirers } & \multicolumn{2}{|c|}{ Serial Acquirers } & \multicolumn{3}{|c|}{ Nonserial Acquirers } & \multirow{2}{*}{\multicolumn{2}{|c|}{$\begin{array}{c}\text { Difference in } \\
\text { Means (Serial- } \\
\text { Nonserial) }\end{array}$}} \\
\hline & $\mathbf{N \#}$ & CAR (- & $+2)$ & $\mathbf{N \#}$ & CAR $(-2,+2)$ & $\mathbf{N} \#$ & CAR ( & $,+2)$ & & \\
\hline & 748 & $\begin{array}{r}-0.0068 \\
0.0015\end{array}$ & $* * *$ & 411 & $\begin{array}{r}-0.0032 \\
0.0019\end{array}$ & 337 & $\begin{array}{r}-0.0111 \\
0.0024\end{array}$ & *** & 0.0079 & $* *$ \\
\hline Non-deregulatory Period & 634 & $\begin{array}{r}-0.0039 \\
0.0017\end{array}$ & $* *$ & 132 & $\begin{array}{r}-0.0029 \\
0.0031\end{array}$ & 502 & $\begin{array}{r}-0.0042 \\
0.0019\end{array}$ & $* *$ & 0.0013 & \\
\hline Difference in Means & & 0.0029 & & & 0.0004 & & 0.0070 & $* *$ & & \\
\hline
\end{tabular}

Note: This table reports the mean five-day CAR for acquisitions which occurred during the period of deregulation and outside of deregulation. We also include the acquirer's acquisition frequency (serial versus nonserial acquirer). Standard errors are listed below the mean CAR and statistical significance is indicated by $* * *, * *$, and * for $1 \%, 5 \%$, and $10 \%$, respectively.

\section{Industry Deregulation}

Due to the regulatory changes enacted during the sample period and their impact on acquisitions, we report returns from deals announced during the two regulatory regimes in Table 5. Serial acquirers engage in more acquisitions during the deregulatory period, whereas the opposite is true for nonserial acquirers. Our full sample results show negative, significant returns; however, returns do not vary statistically between the two periods. We find returns for serial acquirers during the deregulatory (non-deregulatory) period are negative (insignificant) but do not differ statistically. Nonserial acquirers generate negative returns with deregulatory period returns being significantly lower than returns from the non-deregulatory period by 0.7 percent. Serial acquirers outperform nonserial acquirers by nearly 1 percent during the deregulatory period.

Last, we focus on returns generated from deals that are focusing, diversifying, both, or neither with respect to activity and location, conditional on the regulatory environment (Table 6). Overall, we document negative, significant returns. In four cases, we find statistically significant differences in mean returns: (1) operationally focusing (SIC_SIM) deals yield lower returns during the deregulatory period relative to the non-deregulatory period; (2) operationally diversifying (SIC_SIM) deals result in returns about 3 percent higher during the deregulatory period compared to those in the non-deregulatory period; (3) during the deregulatory period, operationally focusing acquisitions (BS_SIM) generate lower returns than diversifying acquisitions; and (4) dually focusing acquisitions produce returns higher than jointly diversifying announcements during the non-deregulatory period (SIC_SIM). In unreported results, we show a difference in returns between dually diversifying and mixed diversifying/focusing acquisitions, during the non-deregulatory period (SIC_SIM).

Excluding the diversifying/focusing aspect of the deals, our results indicate returns are different for deals announced during the two regulatory regimes (consistent with Becher \& Campbell, 2005) but only for nonserial acquirers, which performed worse during the deregulatory period. Our analysis also suggests the market differentiated somewhat by deal focus/diversification attributes with activity focusing (diversifying) deals in the non-deregulatory (deregulatory) period generating better returns (SIC_SIM). 
TABLE 6

FIVE-DAY ANNOUNCEMENT PERIOD CUMULATIVE ABNORMAL RETURNS (CARS) BY REGULATORY ENVIRONMENT

\begin{tabular}{|c|c|c|c|c|c|c|c|c|}
\hline \multirow{3}{*}{ Geographical Diversification/Focus } & \multicolumn{3}{|c|}{ Deregulatory Period } & \multicolumn{3}{|c|}{$\begin{array}{l}\text { Non-deregulatory } \\
\text { Period }\end{array}$} & \multicolumn{2}{|c|}{$\begin{array}{l}\text { Difference in } \\
\text { Means }\end{array}$} \\
\hline & \multirow{3}{*}{$\begin{array}{l}\mathbf{N \#} \\
352\end{array}$} & \multicolumn{2}{|c|}{$\operatorname{CAR}(-2,+2)$} & \multirow{2}{*}{$\begin{array}{l}\mathbf{N} \# \\
271\end{array}$} & \multicolumn{2}{|c|}{$\operatorname{CAR}(-2,+2)$} & & \\
\hline & & & & & & & & \\
\hline Diversifying & & $\begin{array}{r}-0.0090 \\
0.0020\end{array}$ & $* * *$ & & $\begin{array}{r}-0.0038 \\
0.0025\end{array}$ & & -0.0052 & \\
\hline Focusing & 396 & $\begin{array}{r}-0.0048 \\
0.0022\end{array}$ & $* *$ & 363 & $\begin{array}{r}-0.0039 \\
0.0022\end{array}$ & $*$ & -0.0009 & \\
\hline Difference in Means (Focusing - Diversifying) & & 0.0042 & & & -0.0001 & & & \\
\hline \multicolumn{9}{|l|}{ Operational Diversification/Focus } \\
\hline Diversifying & 29 & $\begin{array}{l}0.0099 \\
0.0147\end{array}$ & & 49 & $\begin{array}{r}-0.0212 \\
0.0074\end{array}$ & $* * *$ & 0.0311 & * \\
\hline Focusing & 719 & $\begin{array}{r}-0.0075 \\
0.0015\end{array}$ & & 585 & $\begin{array}{r}-0.0024 \\
0.0017\end{array}$ & & -0.0050 & $* *$ \\
\hline Difference in Means (Focusing - Diversifying) & & -0.0174 & & & -0.0187 & & & \\
\hline \multicolumn{9}{|l|}{ Activity Measure: BS_SIM } \\
\hline Diversifying & 196 & $\begin{array}{r}-0.0064 \\
0.0031\end{array}$ & $* *$ & 178 & $\begin{array}{r}-0.0041 \\
0.0029\end{array}$ & & -0.0023 & \\
\hline Focusing & 243 & $\begin{array}{r}-0.0096 \\
0.0029\end{array}$ & $* * *$ & 220 & $\begin{array}{r}-0.0079 \\
0.0031\end{array}$ & & -0.0017 & \\
\hline Difference in Means (Focusing - Diversifying) & & -0.0031 & $* *$ & & -0.0038 & & & \\
\hline $\begin{array}{l}\text { Activity Measure: IS_SIM } \\
\text { Diversifying }\end{array}$ & 138 & $\begin{array}{r}-0.0074 \\
0.0037\end{array}$ & $* *$ & 171 & $\begin{array}{r}-0.0056 \\
0.0024\end{array}$ & $* *$ & -0.0018 & \\
\hline Focusing & 301 & $\begin{array}{r}-0.0085 \\
0.0026\end{array}$ & $* * *$ & 227 & $\begin{array}{r}-0.0067 \\
0.0033\end{array}$ & $* *$ & -0.0018 & \\
\hline Difference in Means (Focusing - Diversifying) & & 0.0012 & & & 0.0012 & & & \\
\hline \multicolumn{9}{|l|}{$\begin{array}{l}\text { Geographic \& Operational Diversification/Focus } \\
\text { Activity Measure: SIC }\end{array}$} \\
\hline Dually Diversifying & 8 & $\begin{array}{r}-0.0402 \\
0.0250\end{array}$ & & 21 & $\begin{array}{r}-0.0161 \\
0.0056\end{array}$ & $* * *$ & -0.0241 & \\
\hline Focusing \& Diversifying & 393 & $\begin{array}{r}-0.0062 \\
0.0020\end{array}$ & $* * *$ & 250 & $\begin{array}{l}0.0048 \\
0.0029\end{array}$ & * & -0.0014 & \\
\hline Dually Focusing & 404 & $\begin{array}{r}-0.0055 \\
0.0021\end{array}$ & $* * *$ & 306 & $\begin{array}{r}-0.0034 \\
0.0023\end{array}$ & & -0.0021 & \\
\hline Difference in Means (Focusing - Diversifying) & & 0.0347 & & & 0.0127 & $* *$ & & \\
\hline \multicolumn{9}{|l|}{ Activity Measure: BS_SIM } \\
\hline Dually Diversifying & 89 & $\begin{array}{r}-0.0042 \\
0.0381\end{array}$ & & 65 & $\begin{array}{r}-0.0040 \\
0.0042\end{array}$ & & -0.0003 & \\
\hline Focusing \& Diversifying & 242 & $\begin{array}{r}-0.0093 \\
0.0029\end{array}$ & $* * *$ & 176 & $\begin{array}{r}-0.0080 \\
0.0032\end{array}$ & $* *$ & -0.0013 & \\
\hline Dually Focusing & 138 & $\begin{array}{r}-0.0063 \\
0.0040\end{array}$ & & 127 & $\begin{array}{r}-0.0075 \\
0.0043\end{array}$ & $*$ & 0.0012 & \\
\hline Difference in Means (Focusing - Diversifying) & & -0.0021 & & & -0.0035 & & & \\
\hline $\begin{array}{l}\text { Activity Measure: IS_SIM } \\
\text { Dually Diversifying }\end{array}$ & 83 & $\begin{array}{r}-0.0058 \\
0.0044\end{array}$ & & 78 & $\begin{array}{r}-0.0053 \\
0.0030\end{array}$ & * & -0.0005 & \\
\hline Focusing \& Diversifying & 198 & $\begin{array}{r}-0.0095 \\
0.0030\end{array}$ & $* * *$ & 141 & $\begin{array}{r}-0.0083 \\
0.0036\end{array}$ & $* *$ & -0.0012 & \\
\hline Dually Focusing & 188 & $\begin{array}{r}-0.0061 \\
0.0036\end{array}$ & * & 149 & $\begin{array}{r}-0.0066 \\
0.0040\end{array}$ & & 0.0005 & \\
\hline Difference in Means (Focusing - Diversifying) & & -0.0003 & & & -0.0012 & & & \\
\hline
\end{tabular}

Note: This table reports the five-day CARs for acquisitions which occurred during the period of deregulation and outside of deregulation as well as for the geographic and/or operational diversification/focus the acquisition provided the acquirer. Standard errors are reported below the CARs and statistical significance is indicated by $* * *, * *$, and $*$ for $1 \%, 5 \%$, and $10 \%$, respectively. 


\section{Cross-sectional Results}

We incorporate variables noted previously and additional control variables to examine their relationship with CARs in cross-sectional regressions. We provide our regression coefficients along with robust standard errors in Table 7. Model 1 is the base model and Models 2 through 7 introduce various measures and combinations of diversification/focus. In Model 8, we introduce an interaction term.

We document fairly consistent results across all regression model specifications. Our findings are as follows: (1) positive reaction to announcements by serial acquirers; (2) negative reaction to acquisitions of public targets; and (3) deregulatory period announcements negatively influence CARs, for the full sample. Model 8, which includes a serial acquirer and deregulatory period interaction term, yields a significant coefficient for deregulatory period and target public status variables only. The insignificant interaction term coefficient suggests that serial acquirer announcement returns during the deregulatory period are not statistically different than those from the non-deregulatory period, after controlling for other firm and deal characteristics, which is consistent with an insignificant serial acquirer coefficient. The negative, significant deregulatory period coefficient, however, suggests a negative relationship between nonserial acquirers and CARs during the deregulatory period. Our results show all other variables are largely insignificant.

Although not reported, we largely find qualitatively similar results in regressions that incorporate bank specific measures. Due to the fundamental structural differences of banks relative to other industrial firms (e.g., high leverage levels), the additional variables include loan-asset composition and income sources, as outlined previously, as well as acquirer leverage (debt-equity ratio) and cash position (cash-tototal assets ratio). Acquirers who are cash-rich and/or not overly levered have more choice in their financing method, and can control their payment selection and related market signals. Our analysis further reveals a positive, significant AG_Loans coefficient across various model specifications and one model specification yields a negative, significant NONINT coefficient, when the loan-asset variables are excluded. 
TABLE 7

CROSS-SECTIONAL REGRESSIONS

\begin{tabular}{|c|c|c|c|c|c|c|c|c|}
\hline \multirow[b]{2}{*}{ Serial } & \multicolumn{2}{|c|}{ (1) } & \multicolumn{2}{|c|}{ (2) } & \multicolumn{2}{|c|}{ (3) } & \multicolumn{2}{|c|}{ (4) } \\
\hline & 0.0054 & $* *$ & 0.0058 & $* *$ & 0.0077 & $* *$ & 0.0077 & $* *$ \\
\hline & 0.0025 & & 0.0026 & & 0.0036 & & 0.0036 & \\
\hline \multirow{2}{*}{ Equity Used } & -0.0017 & & -0.001 & & -0.0014 & & -0.0014 & \\
\hline & 0.0026 & & 0.0026 & & 0.0038 & & 0.0038 & \\
\hline \multirow{2}{*}{ Public Target } & -0.0140 & $* * *$ & -0.0137 & $* * *$ & -0.0141 & $* * *$ & -0.0141 & $* * *$ \\
\hline & 0.0023 & & 0.0023 & & 0.0030 & & 0.0030 & \\
\hline \multirow[t]{2}{*}{ Ln Relative Size } & 0.0001 & & -0.0000 & & 0.0002 & & 0.0002 & \\
\hline & 0.0009 & & 0.0009 & & 0.0013 & & 0.0013 & \\
\hline \multirow[t]{2}{*}{ ROE } & -0.0297 & & -0.0277 & & -0.0055 & & -0.0060 & \\
\hline & 0.0296 & & 0.0296 & & 0.0408 & & 0.0407 & \\
\hline \multirow[t]{2}{*}{ Deregulatory Period } & -0.0044 & $*$ & -0.0046 & * & -0.0049 & & -0.0047 & \\
\hline & 0.0024 & & 0.0024 & & 0.0032 & & 0.0033 & \\
\hline \multirow[t]{2}{*}{ Intrastate } & & & 0.0019 & & 0.0032 & & 0.0034 & \\
\hline & & & 0.0022 & & 0.0030 & & 0.0030 & \\
\hline \multirow[t]{2}{*}{ SIC_SIM } & & & 0.0034 & & & & & \\
\hline & & & 0.0073 & & & & & \\
\hline \multirow{2}{*}{ BS_SIM } & & & & & 0.0019 & & & \\
\hline & & & & & 0.0029 & & & \\
\hline \multirow[t]{2}{*}{ IS_SIM } & & & & & & & -0.0015 & \\
\hline & & & & & & & 0.0030 & \\
\hline \multirow[t]{2}{*}{ Intercept } & 0.0070 & & 0.0021 & & -0.0005 & & 0.0015 & \\
\hline & 0.0054 & & 0.0089 & & 0.0081 & & 0.0078 & \\
\hline $\mathrm{N}$ & 1382 & & 1382 & & 837 & & 837 & \\
\hline \multirow{2}{*}{$\begin{array}{l}\mathrm{N} \\
\mathrm{R}^{2}\end{array}$} & 0.0342 & & 0.0350 & & 0.0341 & & 0.0339 & \\
\hline & (5) & & (6) & & (7) & & (8) & \\
\hline \multirow{2}{*}{ Serial } & 0.0051 & $* *$ & 0.0072 & $* *$ & 0.0073 & $* *$ & 0.0004 & \\
\hline & 0.0025 & & 0.0035 & & 0.0035 & & 0.0043 & \\
\hline \multirow[t]{2}{*}{ Equity Used } & -0.0017 & & -0.0012 & & -0.0013 & & -0.0019 & \\
\hline & 0.0026 & & 0.0038 & & 0.0037 & & 0.0026 & \\
\hline \multirow[t]{2}{*}{ Public Target } & -0.0141 & $* * *$ & -0.0142 & $* * *$ & -0.0144 & $* * *$ & -0.0139 & $* * *$ \\
\hline & 0.0022 & & 0.0030 & & 0.0030 & & 0.0023 & \\
\hline \multirow{2}{*}{ Ln Relative Size } & 0.0003 & & 0.0005 & & 0.0005 & & 0.0001 & \\
\hline & 0.0009 & & 0.0013 & & 0.0013 & & 0.0009 & \\
\hline ROE & -0.0316 & & -0.0086 & & -0.0082 & & -0.0296 & \\
\hline & 0.0296 & & 0.0408 & & 0.0408 & & 0.0296 & \\
\hline Deregulatory Period & -0.0045 & $*$ & -0.0048 & & -0.0048 & & -0.0064 & $* *$ \\
\hline & 0.0024 & & 0.0032 & & 0.0032 & & 0.0030 & \\
\hline Serial X Deregulatory Period & & & & & & & 0.0071 & \\
\hline & & & & & & & 0.0051 & \\
\hline Dual Focus (SIC_SIM) & 0.0021 & & & & & & & \\
\hline & 0.0022 & & & & & & & \\
\hline Dual Focus (BS_SIM) & & & -0.0016 & & & & & \\
\hline & & & 0.0018 & & & & & \\
\hline Dual Focus (IS_SIM) & & & & & -0.0009 & & & \\
\hline & & & & & 0.0018 & & & \\
\hline Intercept & 0.0050 & & 0.0057 & & 0.0049 & & 0.0080 & \\
\hline & 0.0057 & & 0.0081 & & 0.0078 & & 0.0055 & \\
\hline $\mathrm{N}$ & 1382 & & 837 & & 837 & & 1382 & \\
\hline $\mathrm{R}^{2}$ & 0.0348 & & 0.0332 & & 0.0327 & & 0.0354 & \\
\hline
\end{tabular}

Note: In this table, we report cross-sectional regression coefficients. The dependent variable is the five-day CAR. Robust standard errors are reported below the coefficients and statistical significance is indicated by $* * *, * *$, and * for $1 \%$, $5 \%$, and $10 \%$, respectively. 


\section{CONCLUSION}

In this study, we explore acquirer announcement returns for acquisitions diversifying or focusing the bidding firm geographically and/or operationally. We use a sample of bank M\&As, classified by acquisition frequency as serial or nonserial acquirers, which engage in M\&As during a period which includes substantive industry deregulation. Given the additional considerations of acquisition frequency and industry deregulation, reexamining the diversification versus focus argument provides a unique environment to explore potential firm motivations and market reactions to acquisition announcements.

Overall, M\&As in our sample generate negative acquirer returns, consistent with existing literature. In some cases, serial acquirers outperform nonserial acquirers, suggesting that the bidder's appetite for acquisitions matters. Serial acquirers engage in more geographically-diverse deals than nonserial acquirers, and a majority of targets are operationally similar to the acquirer. With few exceptions, we find little evidence of differences in market reaction based on the diversifying or focusing nature of the deal.

This study focuses on a unique time in the financial industry. Due to the legislative actions instituted, firm behavior changed, and, as a result, so did the market for M\&As (Brewer et al., 2000; Flannery, 1999). Deregulation impacted bidder returns; however, the effects are somewhat isolated. Acquirers experience considerably lower deal announcement returns during the deregulatory period. We link this difference to a surge in competition for targets and increased merger premiums. In particular, deregulation adversely affected nonserial acquirers the most and they underperform serial acquirers during this time.

Were serial acquirers able to exploit the knowledge and expertise gained from previous deals to take advantage of the new operating environment? We believe they may, in fact, have been able to do so as they found themselves in the unique position to leverage their knowledge and expertise in this ultracompetitive M\&A environment to perform better, relative to non- or less-experienced nonserial acquirers. This suggests that repetition helps facilitate success, consistent with conclusions of learning hypothesis focused studies (Aktas, de Bodt, \& Roll, 2013) as well as opinions of industry advisors. Steve Allan, M\&A Practice Leader for Europe for Towers Watson, states, “...experience and access to expertise are invaluable. Experienced acquirers, doing regular deals, are able to build up internal expertise and learn from the deal process" (2011, p. 1).

Our study highlights how such industry shocks affect industries and their overall structure, as evidenced by the growth in too-big-to-fail, mega, and super-regional banks as well as the reduction in small and regional institutions over time. Additionally, our results point-out that bidder acquisition experience matters and further underscores the significance of including nonpublicly traded firms, a classification to which many small and regional institutions belong. Overall, our findings provide motivation for additional research on the performance of nonpublicly traded acquirers in merger and acquisition deals. As with any study, certain limitations exist. This study focuses on one highly regulated industry which experienced substantial deregulation. Consequently, extrapolation and generalizations to other industries and/or other time periods should be regarded with the appropriate level of caution. 


\section{ENDNOTES}

1. Source: http://www.fdic/gov/bank/statistical/stats/2011dec/fdic.pdf.

2. At this time, some states had already began the process of deregulation. About one-third of U.S. states only allowed banks headquartered in other states to hold deposits ranging from 10-30 percent of the state's total deposits. Hawaii allowed no out-of-state banking. Many other states had reciprocity agreements in place (regionally or nationally).

3. We omit merger and acquisition deals announced after December 31, 2007 to avoid confounding effects of the onset of the 2008 financial crisis.

\section{ACKNOWLEDGMENTS}

This research was partially supported by the Georgia Southern University Parker College of Business.

\section{REFERENCES}

Aktas, N., de Bodt, E., \& Roll, R. (2013). Learning from repetitive acquisitions: Evidence from the time between deals. Journal of Financial Economics, 108(1), 99-117.

Al Rahahleh, N., \& Wei, P. P. (2012). The performance of frequent acquirers: Evidence from emerging markets. Global Finance Journal, 23, 16-33.

Allan, S. (2011). Experience counts: Markets favour frequent acquirers. [Online] Retrieved from https://www.towerswatson.com/en/Press/2011/01/Experience-counts-Markets-favour-frequentacquirers. (January 24, 2011)

Becher, D. A. (2009). Bidder returns and merger anticipation: Evidence from banking deregulation. Journal of Corporate Finance, 15(1), 85-98.

Becher, D. A., \& Campbell II, T. L. (2005). Interstate banking deregulation and the changing nature of bank mergers. Journal of Financial Research, 28(1), 1-20.

Berger, A. N., \& DeYoung, R. (2001). The effects of geographic expansion on bank efficiency. Journal of Financial Services Research, 19(2/3), 163-184.

Boubakri, N., Chan, A., \& Kooli, M. (2012). Are the busiest really the best? Further evidence from frequent acquirers. Journal of Multinational Financial Management, 22, 1-23.

Bouwman, C., Fuller, K., \& Nain, A. (2009). Market valuation and acquisition quality: Empirical evidence. Review of Financial Studies, 22(2), 633-679.

Brewer III, E., Jackson III, W. E., Jagtiani, J. A., \& Nguyen, T. (2000). The price of bank mergers in the 1990s. Federal Reserve Bank of Chicago Economic Perspectives, March, 2-23.

Brown, S. J., \& Warner, J. B. (1985). Using daily stock returns: The case of event studies. Journal of Financial Economics, 14(1), 3-31.

Bruner, R. F. (2004). Applied mergers and acquisitions. New Jersey: Wiley.

Chang, S. (1998). Takeovers of privately held targets, methods of payment, and bidder returns. Journal of Finance, 53(2), 773-784.

Cornett, M. M., \& De, S. (1991a). Common stock returns in corporate takeover bids: Evidence from interstate bank mergers. Journal of Banking and Finance, 15(2), 273-295.

Cornett, M. M., \& De, S. (1991b). Medium of payment in corporate acquisitions: Evidence from interstate bank mergers. Journal of Money, Credit, and Banking, 23(4), 767-776.

Cornett, M. M., \& Tehranian, H. (1992). Changes in corporate performance Associated with bank acquisitions. Journal of Financial Economics, 31(2), 211-234.

Cornett, M. M., McNutt, J. J. \& Tehranian, H. (2006). Performance changes around bank mergers: Revenue enhancements versus cost reduction. Journal of Money, Credit, and Banking, 38(4), 1013-1050. 
Croci, E., \& Petmezas, D. (2009). Why do managers make serial acquisitions? An investigation of performance predictability in serial acquisitions (Working paper). Catholic University of the Sacred Heart of Milan, Italy.

DeLong, G. L. (2001). Stockholder gains from focusing versus diversifying bank mergers. Journal of Financial Economics, 59, 221-252.

DeYoung, R., Evanoff, D. D., \& Molyneux, P. (2009). Mergers and acquisitions of financial institutions: A review of the post-2000 literature. Journal of Financial Services Research, 36(2-3), 87-110.

Dickerson, A. P., Gibson, H. D., \& Tsakalotos, E. (1997). The impact of acquisitions on company performance: Evidence from a large panel of UK firms. Oxford Economic Papers, 49(3), 344361.

Egger, P., \& Hahn, F. R. (2010). Endogenous bank mergers and their impact on banking performance: Some evidence from Austria. International Journal of Industrial Organization, 28(2), 155-166.

Flannery, M. (1999). Comment on Milbourn, Boot, and Thakor. Journal of Banking and Finance, 23, 215-220.

Fuller, K., Netter, J., \& Stegemoller, M. (2002). What do returns to acquiring firms tell us? Evidence from firms that make many acquisitions. Journal of Finance, 57(4), 1763-1793.

Goetz, M. R, Laeven, L., \& Levine, R. (2013). Identifying the valuation effects and agency costs of corporate diversification: Evidence from the geographic diversification of U.S. banks. Review of Financial Studies, 26(7), 1787-1823.

Gorton, G., Kahl, M., \& Rosen, R. J. (2009). Eat or be eaten: A theory of mergers and firm size. Journal of Finance, 64(3), 1291-1344.

Gupta, A., \& Misra, L. (2007). Deal size, bid premium, and gains in bank mergers: The impact of managerial motivations. Financial Review, 42(3), 373-400.

Hansen, R. G., \& Lott, Jr., J. R. (1996). Externalities and corporate objectives in a world with diversified shareholders/consumers. Journal of Financial and Quantitative Analysis, 31(1), 43-68.

Harford, J., Humphery-Jenner, M., \& Powell, R. (2012). The sources of value destruction in acquisitions by entrenched managers. Journal of Financial Economics, 106, 247-261.

Houston, J. F., \& Ryngaert, M. D. (1994). The overall gains from large bank mergers. Journal of Banking and Finance, 18, 1155-1176.

Houston, J. F., James, C. M. \& Ryngaert. M. D. (2001). Where do merger gains come from? Bank mergers from the perspective of insiders and outsiders. Journal of Financial Economics, 60(2-3), 285-331.

Hughes, J. P., Lang, W. W., Mester, L. J., \& Moon, C. (1999). The dollars and sense of bank consolidation. Journal of Banking and Finance, 23, 291-324.

Huyghebaert, N., \& Luypaert, M. (2013). Sources of synergy realization in mergers and acquisitions: Empirical evidence from nonserial acquirers in Europe. International Journal of Financial Research, 4(2), 49-67.

Ismail, A. (2008). Which acquirers gain more, single or multiple? Recent evidence from the USA market. Global Finance Journal, 19(1), 72-84.

Jouida, S., Bouzgarrou, H., \& Hellara, S. (2017). The effects of activity and geographic diversification on performance: Evidence from French financial institutions. Research in International Business and Finance, 39, 920-939.

Knapp, M., Gart, A., \& Becher, D. (2005). Post-merger performance of bank holding companies, 19871998. Financial Review, 40, 549-574.

Laamanen, T., \& Keil, T. (2008). Performance of serial acquirers: Toward an acquisition program perspective. Strategic Management Journal, 29, 663-672.

Laeven, L., \& Levine, R. (2007). Is there a diversification discount in financial conglomerates? Journal of Financial Economics, 85(2), 331-367.

Moeller, S. B., Schlingemann, F. P., \& Stulz, R. M. (2003). Do shareholders of acquiring firms gain from acquisitions? (Working paper), National Bureau of Economic Research, Massachusetts. 
Moeller, S. B., Schlingemann, F. P., \& Stulz. R. M. (2004). Firm size and the gains from acquisitions. Journal of Financial Economics, 73(2), 201-228.

Moeller, S. B., Schlingemann, F. P., \& Stulz, R. M. (2005). Wealth destruction on a massive scale. Journal of Finance, 60(2), 757-782.

Ooghe, H., De Langhe, T., \& Camerlynck, J. (2006). Profile of multiple versus single acquirers and their targets: A research note. Applied Economics, 38(7), 725-733.

Ramaswamy, K. (1997). The performance impact of strategic similarity in horizontal mergers: Evidence from the U.S. banking industry. Academy of Management Journal, 40(3), 697-715.

Sawada, M. (2013). How does the stock market value bank diversification? Empirical evidence from Japanese banks. Pacific-Basin Finance Journal, 25, 40-61.

Schmid, M. M., \& Walter, I. (2009). Do financial conglomerates create or destroy economic value? Journal of Financial Intermediation, 18(2), 193-216.

Schmid, M. M., \& Walter, I. (2012). Geographic diversification and firm value in the financial services industry. Journal of Empirical Finance, 19, 109-122.

Sherman, H. D., \& Rupert, T. J. (2006). Do bank mergers have hidden or foregone value? Realized and unrealized operating synergies in one bank merger. European Journal of Operational Research, $168,253-268$.

Stiroh, K. J. (2004). Diversification in banking: Is noninterest income the answer? Journal of Money, Credit, and Banking, 36(5), 853-882.

Sudarsanam, S., Holl, P., \& Salami, A. (1996). Shareholder wealth gains in mergers: Effect of synergy and ownership structure. Journal of Business Finance and Accounting, 23(5/6), 673-698.

Walker, M. M. (2000). Corporate takeovers, strategic objectives, and acquiring-firm shareholder wealth. Financial Management, 29(1), 53-66. 